\title{
Comparative Marker Selection
}

National Cancer Institute

\section{Source}

National Cancer Institute. Comparative Marker Selection. NCI Thesaurus. Code C64198.

An algorithm for assigning significance values to genes being tested for their ability to discriminate between microarray samples. 